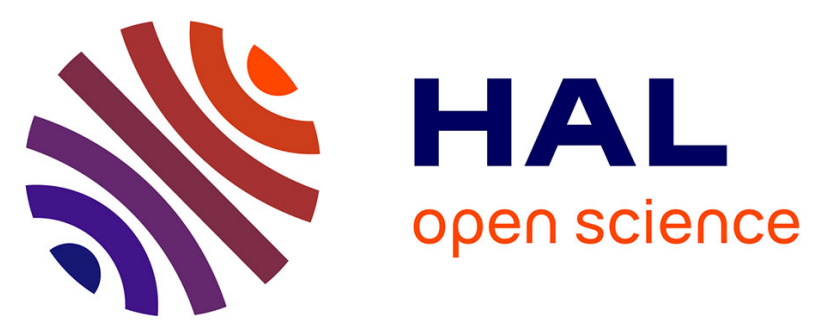

\title{
Roles of regional hydrodynamic and trophic contamination in cadmium bioaccumulation by Pacific oysters in the Marennes-Oléron Bay (France)
}

Emilie Strady, Gérard Blanc, Magalie Baudrimont, Jörg Schäfer, Serge Robert, Virginie Lafon

\section{To cite this version:}

Emilie Strady, Gérard Blanc, Magalie Baudrimont, Jörg Schäfer, Serge Robert, et al.. Roles of regional hydrodynamic and trophic contamination in cadmium bioaccumulation by Pacific oysters in the Marennes-Oléron Bay (France). Chemosphere, 2011, 84 (1), pp.80-90. 10.1016/j.chemosphere.2011.02.051 . hal-02357367

\section{HAL Id: hal-02357367 https://hal.science/hal-02357367}

Submitted on 14 Nov 2019

HAL is a multi-disciplinary open access archive for the deposit and dissemination of scientific research documents, whether they are published or not. The documents may come from teaching and research institutions in France or abroad, or from public or private research centers.
L'archive ouverte pluridisciplinaire HAL, est destinée au dépôt et à la diffusion de documents scientifiques de niveau recherche, publiés ou non, émanant des établissements d'enseignement et de recherche français ou étrangers, des laboratoires publics ou privés. 


\title{
Roles of regional hydrodynamic and trophic contamination in cadmium bioaccumulation by Pacific oysters in the Marennes-Oléron Bay (France)
}

\author{
Emilie Strady ${ }^{a}$, , Gérard Blanc ${ }^{a}$, Magalie Baudrimont ${ }^{a}$, Jörg Schäfer ${ }^{a}$, Serge Robert ${ }^{b}$, Virginie Lafon ${ }^{c}$ \\ a University of Bordeaux, UMR 5805 EPOC, GEMA Team, Avenue des Facultés, 33405 Talence, France \\ b IFREMER, LER/PC, BP7, Gaby Coll, 17137 L'Houmeau, France \\ 'Geotransfert, University of Bordeaux, UMR 5805 EPOC, GEMA Team, Avenue des Facultés, 33405 Talence, France
}

a $\mathrm{r}$ tic 1 e i n f o

\section{Article history:}

Received 14 November 2010

Received in revised form 17 February 2011

Accepted 23 February 2011

Available online 21 March 2011

\section{Keywords:}

Cadmium

Oysters

Bioaccumulation

Metallothioneins

Trophic contamination

Regional hydrodynamic

\begin{abstract}
a b s t r a c t
The Marennes-Oléron Bay, hosting the largest oyster production in France, is influenced by the historic polymetallic pollution of the Gironde Estuary. Despite management efforts and decreasing emissions in the Gironde watershed, cadmium levels in oysters from the bay are close to the consumption limit (5 $\left.\mathrm{lg} \mathrm{g}^{-1} \mathrm{dw}, \mathrm{EC}\right)$. From mid April to mid July 2009, we investigated the role of tidal resuspension and regional hydrodynamics on Cd speciation (seawater, SPM, phytoplankton, sediment, microphytobenthos) and bioaccumulation in 18 month-old oysters (gills, digestive glands, rests of tissues) reared under natural conditions (i) at $\sim 60 \mathrm{~cm}$ above the sediment and (ii) on the sediment surface. Dissolved and particulate $\mathrm{Cd}$ concentrations in surface and bottom waters were similar and constant over tidal cycle suggesting the absence of Cd release during sediment resuspension. Temporal dissolved and particulate Cd concentrations were closely related to Gironde Estuary water discharges, showing increasing concentrations during flood situations and decreasing concentrations afterwards. Cd depletion in the water column was associated with increasing $\mathrm{Cd}$ in the $[20-100 \mathrm{~lm}]$ plankton fraction, suggesting $\mathrm{Cd}$ bioaccumulation. After 3 months, enrichment factors of $\mathrm{Cd}$ in tissues of oysters exposed in the water column and directly on the sediment were respectively 3.0 and 2.2 in gills, 4.7 and 3.2 in digestive glands and 4.9 and 3.4 in remaining tissues. Increasing Cdbioaccumulation in gills, digestive glands and remaining tissues can be related to elevated dissolved $\mathrm{Cd}$ in the bay, suggesting gill contamination via the direct pathway and subsequent internal redistribution of $\mathrm{Cd}$ to other organs and tissues. Elevated Cd contents in oysters reared on tables could be attributed to different trophic Cd transfer (phytoplankton versus microphytobenthos) or to different oyster metabolisms between the rearing conditions as suggested by metallothionein concentrations.
\end{abstract}

\section{Introduction}

Characterising cadmium bioaccumulation pathways of oysters in a specific environment is of a high economic concern and remains a present important issue (Baudrimont et al., 2005; Lekhi et al., 2008; Bendell and Feng, 2009; Ng et al., 2010). Oyster production and trade are limited by the Cd consumption safety level, varying from $1 \mathrm{lg} \mathrm{g}^{-1}$ wet weight in the European Union (or $5 \mathrm{lg}$ $\mathrm{g}^{-1}$ dry weight), to $2 \mathrm{lg} \mathrm{g}^{-1} \mathrm{ww}$ in the Hong-Kong market and $4 \mathrm{~g} \mathrm{~g} \mathrm{~g}^{-1} \mathrm{ww}$ in the US (Food and Drug Administration). Because of elevated $\mathrm{Cd}$ levels in oysters, oyster' farms have been closed in the Gironde Estuary, SW France (Baudrimont et al., 2005) and several shipments from BC Canada were rejected in the Hong-Kong market (Kruzynski, 2004). Thus, the understanding

\footnotetext{
$\Uparrow$ Corresponding author. Present address: CEREGE, UMR 6635, BP80 13545 Aix en Provence, France.

E-mail address: e.strady@epoc.u-bordeaux1.fr (E. Strady).
}

of oyster contamination by $\mathrm{Cd}$ in farming environments required investigations on mechanisms and factors influencing and controlling bioaccumulation.

Cadmium bioaccumulation in oysters was characterized as more important by the direct than the trophic pathway of contamination under laboratory and controlled experiments (Reinfelder et al., 1997; Boisson et al., 2003; Barrera-Escorcia et al., 2010; Hédouin et al., 2010; Strady et al., in press). In environments, the preponderant role of dissolved $\mathrm{Cd}$ on bioaccumulation was clearly shown in studies on Vancouver Island, but uncertainties remained concerning the role of particulate $\mathrm{Cd}$ and the trophic pathway (Lekhi et al., 2008). Cd bioaccumulation depends also on location and regional hydrodynamics and can differ from one site to another within a bay (Kruzynski, 2004; RNO, 2006). The influence of environmental factors on bioaccumulation was investigated in breeding basins where it was demonstrated that physico-chemical parameters variations control metal partitioning and recycling and so, strongly influenced metal bioaccumulation (Baudrimont et al., 2005). 
The Marennes-Oléron Bay (MOB) hosts the largest oyster production in France and Europe: 55-60 ton year ${ }^{-1}$, i.e. $50-55 \%$ of French annual production, covering a cultured area of $51 \mathrm{~km}^{2}$. The bay is influenced by the Charente and Seudre Rivers (Fig. 1), but also by the historical polymetallic pollution of the Gironde Estuary waters (Latouche, 1988; Jouanneau et al., 1990; Blanc et al., 1999; Schäfer et al., 2002; Audry et al., 2007; Dabrin et al., 2009). Because of this pollution, the French Mussel Watch program (Réseau National d'Observation, RNO, and recently renamed Réseau d'Observation des Contaminants CHimiques, $\mathrm{ROCCH}$ ), have been surveying $\mathrm{Cd}$ bioaccumulation in wild oysters from the Gironde and the MOB, since the 1970s. While management efforts and decreasing emissions in the Gironde watershed (Audry et al., 2003; Coynel et al., 2007) have resulted in decreased Cd concentrations in oysters, they still remain higher than the consumption limit level (ROCCH, 2010). In the MOB, Cd levels in oysters have also decreased over time and are now lower but close to the limit level since the late 1990s, with higher contents in wild oysters from the southern part of the bay than from the north (ROCCH, 2010).

Previous work on the hydrodynamic context of this area and more precisely the Gironde plume using MODIS imagery, combined with wind and water discharges data, has shown that this plume can extend toward the bay and can be connected to the Antioche Inlet (north) only $1 \%$ of time and connected to the Maumusson Inlet (south) 31\% of time (Dabrin, 2009; Lafon et al., 2009). In this context, we investigated over 3 months the influence of regional hydrodynamic and tidal sediment resuspension on $\mathrm{Cd}$ levels, speciation, and bioaccumulation in young oysters grown under real production conditions at an instrumented experimental site in the southern part of the MOB (Ronce les Bains). In this paper, we present temporal Cd speciation (seawater, suspended particulate matter SPM, phytoplankton, sediments, microphytobenthos), hydrodynamic variations, Cd bioaccumulation kinetics

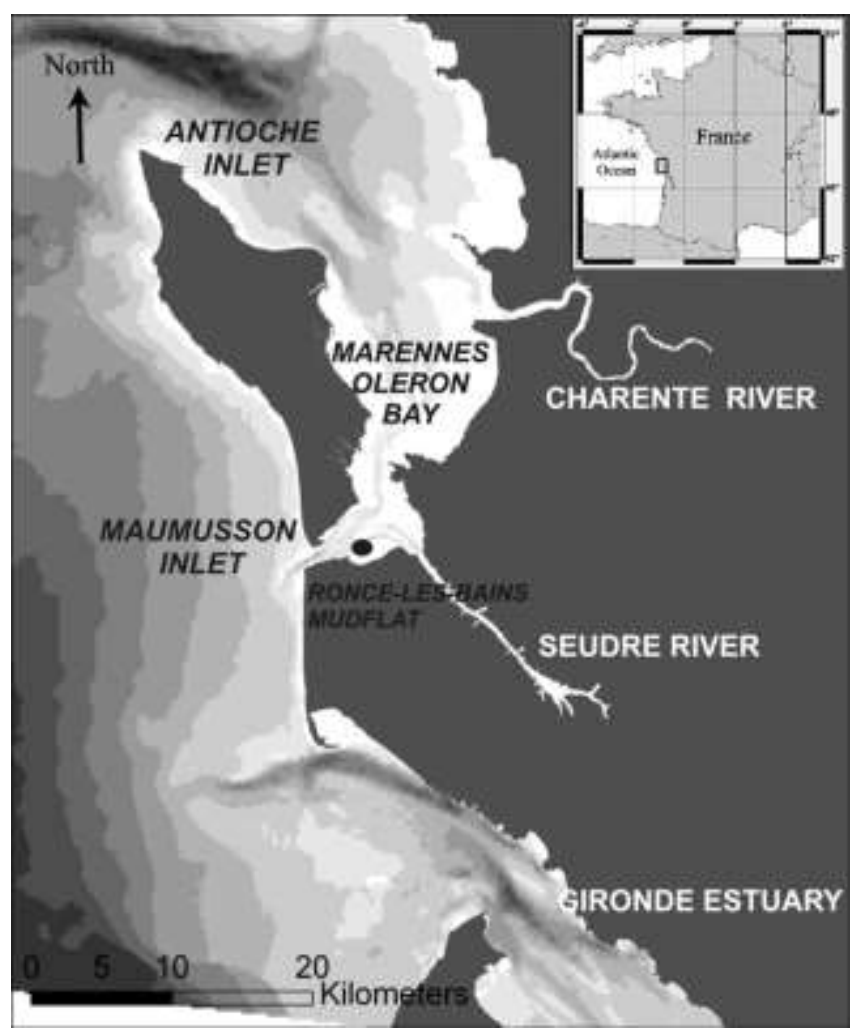

Fig. 1. Location map of the study area and the sampling site, Ronce-Les-Bains mudflat. in gills, digestive gland and in the rest of the tissues and metallothionein concentrations in oysters cultivated under real production conditions, i.e. in bags (i) installed on tables in the water column at $60 \mathrm{~cm}$ above the sediment and (ii) directly on the sediment surface during the 3 month experiment. We investigated the influence of the regional hydrodynamics on $\mathrm{Cd}$ speciation and availability in the area, the role of the direct and the trophic $\mathrm{Cd}$ contamination pathway in oysters, the potential effect of the rearing conditions on bioaccumulation and detoxification processes.

\section{Materials and methods}

\subsection{Study area}

The Marennes-Oléron Bay has a total surface area of $180 \mathrm{~km}^{2}$ and is directly influenced by the Charente River and the Seudre River (10-470 and 0-40 $\mathrm{m}^{3} \mathrm{~s}^{-1}$ respectively, Soletchnik et al., 1998; Fig. 1). The intertidal mudflat area, representing $96 \mathrm{~km}^{2}$, concentrates the major portion of the biomass (Soletchnik et al., 1998; Pigeot et al., 2006). Benthic microalgae produced on these mudflats can be resuspended during the beginning of flood tide by wind-induced resuspension (Guarini et al., 1998). The northto-south residual circulation of marine waters within the bay leads to a residence time varying from 5 to $10 \mathrm{~d}$, depending on tidal (over $6 \mathrm{~m}$ ) and winds conditions (Raillard and Menesguen, 1994).

\subsection{Sampling}

\subsubsection{Sampling strategy}

The survey was conducted from mid April to mid July 2009 at Ronce-Les-Bains site (RLB), an oyster cultured tidal flat in southern MOB (Fig. 1). Sampling was performed every 2 weeks, successively (i) over a 12-h tidal cycle: high tide (HT), mid ebb (ME), first hour of flood (F1), second hour of flood (F2) (Table 1); and (ii) at low tide conditions for oysters sampling. During 12-h tidal cycle, we used a $5 \mathrm{~m}$ flat boat poto-poto to reach the sampling site at high tide and mid-tide. During low tide, we reached the sampling site by foot.

\subsubsection{Seawater}

Surface and bottom seawater were sampled with 1.5 L Niskin bottles and immediately transferred to $\mathrm{HNO}_{3}$ pre-cleaned PP bottles $(1 \mathrm{~L})$. Then, $60 \mathrm{~mL}$ were immediately filtered through $0.2 \mathrm{~mm}$ Nucleopore ${ }^{\circledR}$ polycarbonate filters and another $60 \mathrm{~mL}$ through $0.021 \mathrm{~m}$ Whatman ${ }^{\circledR}$ filters; the filtrating were acidified (ultrapure $\mathrm{HNO}_{3}, 1 / 1000$ ) to a $\mathrm{pH}<2$ and stored in acid pre-cleaned PP bottles at $4{ }^{\circ} \mathrm{C}$ in the dark until cadmium analysis. Larger volumes of seawater (up to $500 \mathrm{~mL}$ ) were filtered through $0.7 \mathrm{~mm}$ Whatman GF/ $\mathrm{F}^{\circledast}$ filters, which were immediately folded and kept in ice-bags a few hours until being kept at $-20{ }^{\circ} \mathrm{C}$ in the dark for chlorophyll-a measurements by a fluorometric method (Yentsch and Menzel, 1963). Surface water was also sampled with a $40 \mathrm{~L}$ can (previously rinsed three times with seawater) for SPM, retrieved in the laboratory by large volume centrifugation. Previously, homogenised 500 $\mathrm{mL}$ sub-samples were filtered through pre-weighted $0.7 \mathrm{~mm}$ Whatman GF/ $\mathrm{F}^{\circledR}$ filters before drying at $50{ }^{\circ} \mathrm{C}$ for $3 \mathrm{~d}$ and weight again for SPM concentrations determination. During low tide sampling, seawater was sampled using $1 \mathrm{~L} \mathrm{HNO}_{3}$ pre-cleaned PP bottles instead of using a Niskin bottle.

As oysters ingest $10-1001 \mathrm{~m}$ particles, we collected plankton using a $201 \mathrm{~m}$ diameter net. Then, in the laboratory, we separated 'particles' above $1001 \mathrm{~m}$, and dried the '20-100 lm phytoplankton' at $50{ }^{\circ} \mathrm{C}$ for $3 \mathrm{~d}$ until metal measurement.

Salinity, temperature, $\mathrm{pH}$, and oxygen levels were measured with crison ${ }^{\circledR}$ probes. 
Twelve hour tidal cycle parameters variations in surface and bottom waters in high tide, mi ebb, first and second hour of flood at Ronce-Les-Bains mudflat during the four sampling date, 20th April, 26th May, 24th June and 09th July 2009.

\begin{tabular}{|c|c|c|c|c|c|c|c|c|c|c|c|c|c|c|c|c|c|}
\hline & & HT & $\mathrm{ME}$ & F1 & $\mathrm{F} 2$ & HT & ME & $\mathrm{F} 1$ & F2 & HT & $\mathrm{ME}$ & $\mathrm{F} 1$ & $\mathrm{~F} 2$ & $\mathrm{HT}$ & ME & F1 & F2 \\
\hline Salinity & $\begin{array}{l}\text { Surface } \\
\text { Bottom }\end{array}$ & 33.2 & 33.3 & 33 & & $\begin{array}{l}32.9 \\
32.9\end{array}$ & 32.9 & 33 & 33 & $\begin{array}{l}33.1 \\
33.1\end{array}$ & $\begin{array}{l}33.2 \\
33.2\end{array}$ & 33.2 & & $\begin{array}{l}33.9 \\
33.9\end{array}$ & $\begin{array}{l}33.8 \\
33.8\end{array}$ & 33.8 & 33.8 \\
\hline Chl-a $\operatorname{lg~L^{-1}}$ & $\begin{array}{l}\text { Surface } \\
\text { Bottom }\end{array}$ & 1 & 1.5 & 3.5 & & 1.9 & 1.9 & 22.9 & 3 & $\begin{array}{l}2.3 \\
3.3\end{array}$ & $\begin{array}{l}1.7 \\
3.9\end{array}$ & 1.3 & & $\begin{array}{l}1.3 \\
2\end{array}$ & $\begin{array}{l}1.8 \\
1.6\end{array}$ & 1.6 & 3 \\
\hline SPM mg L ${ }^{-1}$ & $\begin{array}{l}\text { Surface } \\
\text { Bottom }\end{array}$ & 43 & 45 & 105 & & 34 & 93 & 914 & 240 & $\begin{array}{l}10 \\
10\end{array}$ & $\begin{array}{l}28 \\
140\end{array}$ & 22 & & $\begin{array}{l}9 \\
52\end{array}$ & $\begin{array}{l}34 \\
21\end{array}$ & 47 & 53 \\
\hline $\mathrm{Cd}<0.2 \mathrm{lg} \mathrm{L}^{-1}$ & $\begin{array}{l}\text { Surface } \\
\text { Bottom }\end{array}$ & 0.036 & 0.040 & 0.030 & & $\begin{array}{l}0.038 \\
0.043\end{array}$ & 0.035 & & 0.089 & $\begin{array}{l}0.021 \\
0.020\end{array}$ & $\begin{array}{l}0.024 \\
0.018\end{array}$ & 0.022 & & $\begin{array}{l}0.027 \\
0.027\end{array}$ & $\begin{array}{l}0.022 \\
0.023\end{array}$ & 0.019 & 0.026 \\
\hline $\mathrm{Cd}<0.02 \operatorname{lg~\mathrm {L}^{-1}}$ & $\begin{array}{l}\text { Surface } \\
\text { Bottom }\end{array}$ & 0.028 & 0.039 & 0.031 & & 0.029 & 0.031 & & 0.076 & $\begin{array}{l}0.016 \\
0.020\end{array}$ & $\begin{array}{l}0.023 \\
0.018\end{array}$ & 0.019 & & $\begin{array}{l}0.023 \\
0.028\end{array}$ & $\begin{array}{l}0.019 \\
0.018\end{array}$ & 0.019 & 0.021 \\
\hline $\mathrm{Cd} \mathrm{SPM} \mathrm{mg} \mathrm{kg}^{-1}$ & $\begin{array}{l}\text { Surface } \\
\text { Bottom }\end{array}$ & 1.50 & 0.20 & 0.43 & & $\begin{array}{l}1.81 \\
0.20\end{array}$ & 0.19 & & 0.22 & $\begin{array}{l}0.22 \\
0.23\end{array}$ & 0.28 & & & 0.26 & 0.26 & 0.27 & 0.29 \\
\hline 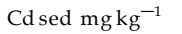 & & 0.10 & & & & 0.14 & & & & 0.35 & & & & 0.17 & & & \\
\hline
\end{tabular}

\subsubsection{Sediments}

Surface sediment $(0-0.5 \mathrm{~cm})$ was sampled using a plastic knife, dried at $50{ }^{\circ} \mathrm{C}$ and powdered until trace metal analysis. Microphytobenthos was sampled at low tide according to two methods. In the first one, the top $5 \mathrm{~mm}$ surface sediment was scraped and epipelic diatoms were isolated from mud samples in the laboratory using their capacity to migrate upwards, as described in Malet et al. (2008). In the second method, we directly separated surface epipelic diatoms (which had migrated) from mud in the field using their capacity to float and aggregate with the beginning of flood tide waters. Thus, with filtered-seawater from the site, we re-created local tidal suspension and collected diatoms just after floating. Microphytobenthos was then dried at $45^{\circ} \mathrm{C}$, powdered, and bagpacked until metal analysis.

\subsubsection{Oysters}

Eighteen months-old oysters, originated from the Cd-uncontaminated Arcachon Basin (RNO, 2006), were placed in six bags ( $n$ $=45$ per bag) installed on tables (T) in the water column $60 \mathrm{~cm}$ above the sediment and directly on the bottom (B), which was actually $5 \mathrm{~cm}$ above the sediment to avoid burying by sedi- ment deposition processes. Oyster bags from each condition were sampled after 1, 2 and 3 months and kept refrigerated at $4{ }^{\circ} \mathrm{C}$ in the dark until dissection the day after. Then, shells and tissues were separately weighed, and tissues were dissected into gills (G), digestive glands (DG) and remaining tissues (R), which were weighed, dried at $60{ }^{\circ} \mathrm{C}$ during $3 \mathrm{~d}$ and weight again. Sub-samples of $\mathrm{G}$ and DG (2/3 of masses) and whole $\mathrm{R}$ were kept at $-20{ }^{\circ} \mathrm{C}$ until cadmium analysis whereas the other $1 / 3$ of G and DG masses were kept at $-80{ }^{\circ} \mathrm{C}$ under $\mathrm{N}_{2}$-atmosphere until metallothionein measurements. Those sub-samples were analysed and measured separately without pooling oysters together.

\subsection{Analysis}

\subsubsection{Dissolved and particulate $\mathrm{Cd}$}

Dissolved $\mathrm{Cd}(<0.2 \mathrm{~lm})$ and truly dissolved $\mathrm{Cd}(<0.02 \mathrm{~lm})$ were extracted from seawater by solid-liquid extraction (Strady et al., 2009) and measured by ICP-MS (Thermo X7). The Cd colloidal fraction was then achieved by doing the difference between $<0.21 \mathrm{~m}$ and $<0.021 \mathrm{~m}$.

Representative sub-samples of surface sediments, SPM, (20$100 \mathrm{~lm})$ plankton and microphytobenthos $(30 \mathrm{mg}$ of dried, powdered and homogenized material) were digested into acidpre-cleaned PP-tubes (SCP sciences ${ }^{\circledR}$ ) using $1 \mathrm{~mL} \mathrm{HNO}_{3}(14 \mathrm{M}$, suprapur $\left.^{\circledR}\right), 3 \mathrm{~mL} \mathrm{HCl}\left(12 \mathrm{M}\right.$, suprapur $\left.{ }^{\circledR}\right)$ and $2.5 \mathrm{~mL} \mathrm{HF} \mathrm{(26} \mathrm{M,}$ suprapur $\left.{ }^{\circledR}\right)$. The reactors were heated at $110^{\circ} \mathrm{C}$ for $2 \mathrm{~h}$ using a temperature controlled digestion system DigiPrep ${ }^{\circledR}$ (SCP sciences).

After cooling, the digested solution was evaporated until dryness, and the digestate were diluted to $10 \mathrm{~mL}$ using $2501 \mathrm{~L}^{\mathrm{HNO}_{3}}$ (14 M, suprapur $\left.{ }^{\circledR}\right)$ and milli-Q water ${ }^{\circledR}$. Trace metal concentrations were measured by ICP-MS (Thermo X7).

Analyses were quality controlled using certified seawater (CASS-4; $98 \pm 3 \%$ accuracy), certified marine sediments (BCSS-1; $97 \pm 8 \%$ accuracy) and measurements by using riverine water (SLRS-4; $99 \pm 5 \%$ accuracy).

\subsubsection{Oysters condition index, Cd bioaccumulation and metallothionein levels}

Oyster condition index during the 3 months was determined individually as the tissue/shell wet weight ratio multiplied by 100 .

To analyse Cd concentrations in oysters, G, DG and R were mineralized during $3 \mathrm{~h}$ in $3 \mathrm{~mL}$ suprapur ${ }^{\circledR} \mathrm{HNO}_{3}$ at $100{ }^{\circ} \mathrm{C}$ (DigiPREP, ${ }^{\circledR} \mathrm{SCP}$ Sciences) and measured by ICP-MS (Thermo X7). Analyses and measurements were quality controlled using respectively lobster hepatopancreas reference material TORT-2 (110 $\pm 2 \%$ accuracy).

Metallothionein levels in oysters G and DG were analyzed by mercury saturation assay (Marie et al., 2006).

\subsection{Statistical analysis}

Statistical analyses were performed on condition index, bioaccumulation and metallothionein data using Statistica ${ }^{\circledR}$ software. When normality and homogeneity of error terms were respected (e.g. condition index and metallothionein), the significant effect of factors taken into account was determined using an analysis of variance method (ANOVA) and a least square deviation test (LSD). When the assumptions were not respected (e.g. bioaccumulation), we used a non-parametric method and the Kruskall-Wallis test. For all statistical results, a probability of $p<0.05$ was considered significant.

\subsection{Satellite data}

The spatial extent and the orientation of the Gironde plume was monitored during the survey using ocean colour MODIS satellite data as described by Lafon et al. (2009). Surface were SPM were quantified using algorithms adapted to the MODIS surface reflectance (Doxaran et al., 2009), allowing SPM quantification at surface water for concentrations lower than $50 \mathrm{mg} \mathrm{L}^{-1}$. Since this algorithm has not been validated so far, it seems reasonable to consider 
SPM values as indicative of an order of magnitude instead as absolute values. However the plume geometry (size and orientation) are correctly represented (Lafon et al., 2009). In order to evaluate the Gironde plume evolution all along the sampling period, four couple of MODIS Aqua full resolution $(250 \mathrm{~m})$ images have been downloaded from the NASA Land Processed Distributed Active Archive Centre. Acquisition dates and times are synthesized on Fig. 4.

\section{Results}

\subsection{Twelve hours tidal cycle: geochemical survey}

Salinity, SPM, Chl-a, dissolved Cd, total particulate Cd concentrations were determined at high tide (HT), mid ebb (ME), first and second hour of flood (F1, F2) of four tidal cycle sampling (20th April, 26th May, 24th June and 9th July 2009; Table 1; Fig. 2). However, during 20th April and 26th May tidal cycles, we observed higher $\mathrm{Cd}$ concentrations in SPM at HT compared to ME, $\mathrm{F} 1$ and F2. Asit will be discussed in the discussion section, those higher concentrations are not due to tidal cycle variations but to a larger influence of the Gironde water flowing into the bay during flood tide via the Maumusson Inlet (Bertin et al., 2005). Despite those specific HT sampling, we observed similar tendencies for each tidal cycle sampling (Table 1). Consequently, we decided to focus on and describe one tidal cycle (9th July), the most complete cycle, representing the other observed tidal cycles variations (Fig. 2). In fact, in some cycle, data are missing because of sampling or analytical issues.

Salinity was constant over the water column and over tidal cycle (Fig. 2). Surface and bottom dissolved $\mathrm{Cd}\left(\mathrm{Cd}_{\mathrm{d}}\right)$ did not vary significantly during ebb and flood sediment resuspension, showing
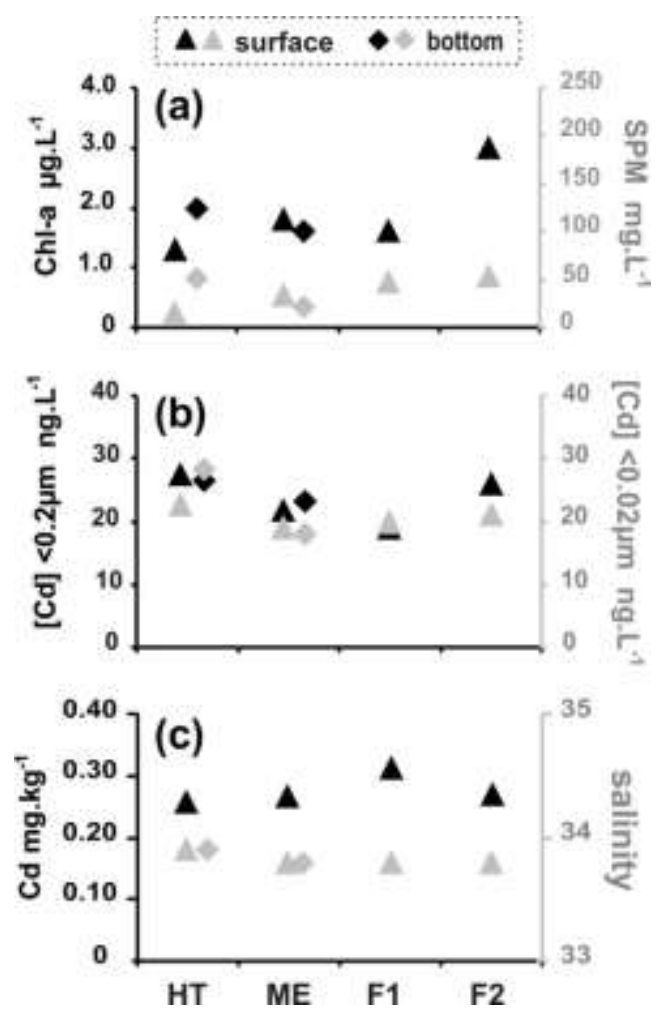

Fig. 2. Twelve hour tidal cycle parameters variations in surface and bottom waters in high tide, mid ebb, first and second hour of flood at Ronce-Les-Bains mudflat (9th July 2009). (a) SPM and Chl-a concentrations $\left(\mathrm{mg} \mathrm{L}^{-1}\right)$; (b) dissolved Cd $(<0.21 \mathrm{~m}$ over $<0.021 \mathrm{~m}$ ) concentrations $\left(\mathrm{ng} \mathrm{L}^{-1}\right)$; (c) particulate Cd concentrations (mg $\mathrm{kg}^{-1}$ ) over salinity. similar values for both fractions $<0.21 \mathrm{~m}$ and $<0.021 \mathrm{~m}$. SPM and Chl-a presented higher surface concentrations during the first and second hour of flood tide (F1 and F2). However, total particu- late $\mathrm{Cd}$ concentrations were constant, over the tidal cycle, even during flood tide suspension.

\subsection{Three months variations}

The hydrological situation in the southern part of MOB was characterised by daily freshwater discharges from the Charente River and the Gironde Estuary, provided by the BanqueHydro ${ }^{\circledR}$ and the Port Autonome de Bordeaux (Fig. 3a). During the 3 months survey, the Charente River daily discharges were typical of mean annual discharges (Soletchnik et al., 1998). In contrast, Gironde Estuary daily discharges were higher than annual mean discharges ( $\sim 800 \mathrm{~m}^{3} \mathrm{~s}^{-1}$, over 1989-2009) from mid April to end of May, with two flood events $\left(>2000 \mathrm{~m}^{3} \mathrm{~s}^{-1}\right)$ on 22nd April and from 28th April to 4 th May.

The position of the Gironde plume changed during the 3 months (Fig. 4). During high Gironde water discharges from mid April to mid May, high turbidity levels in the coastal zone were detected by MODIS images (Fig. $4 \mathrm{a}$ and b). Furthermore, the plume was connected to the MOB at the Maumusson Inlet (south). With decreasing Gironde freshwaters discharges in beginning of June, the plume extension in the coastal area was less important as during high freshwater discharges, and was not connected anymore to the Maumusson inlet (Fig. 4c). Then, during low Gironde freshwaters discharges from mid-June to July, the plume was definitely off the coastal zone and the turbidity zone had moved into the estuary (Fig. 4d). Salinity was rather constant during the survey from 32.2 in April, decreased to 31.5 in early June and increased to 33.9 in mid July (Fig. 3c). These variations are consistent with the salinity measured twice a month at Auger Est (Fig. 1) (RAZLEC-IFREMER, 2009). SPM concentrations at the RLB site were relatively low $\left(<10-90 \mathrm{mg} \mathrm{L}^{-1}\right)$ during the survey and more related to tidal sediment resuspension than hydrologic conditions (Fig. 3d). Chl-a concentrations were in the typical range of the area, from 1 to $6 \mathrm{lg} \mathrm{L}^{-1}$ (Soletchnik et al., 1998), despite that lower concentrations were measured at Auger Est by RAZLEC watch (RAZLEC-IFREMER, 2009). However, we did not observe the typical spring plankton bloom (Malet et al., 2008; RAZLEC-IFREMER, 2009).

Dissolved Cd concentrations $(<0.21 \mathrm{~m}$; Fig. 3c) showed two different temporal patterns. During high Gironde water discharges, concentrations were constant and close to $40 \mathrm{ng} \mathrm{L}^{-1}$ whereas concentrations decreased with decreasing Gironde water discharges to $30 \mathrm{ng} \mathrm{L}^{-1}$ in mid-June and to $20 \mathrm{ng} \mathrm{L}^{-1}$ by the end of June and in July for very low water discharges. Comparison of $<0.2$ and $<0.02$ $\mathrm{Cd}$ concentrations fractions showed that the colloidal $\mathrm{Cd}$ fractions ranged from $0 \%$ to $30 \%$ in waters sampled at $\mathrm{F} 1$ and at $\mathrm{HT}$, respectively (Fig. 3c).

Total particulate $\mathrm{Cd}$ concentrations showed higher concentrations in SPM sampled at HT than at F1 during high Gironde water discharges in April and May (up to $1.5 \mathrm{mg} \mathrm{kg}^{-1}$; Fig. 3e). During mean to low water discharges, Cd concentrations in SPM sampled at $\mathrm{HT}$ and $\mathrm{F} 1$ were significantly lower, close to $0.25 \mathrm{mg} \mathrm{kg}^{-1}$ (Fig. 3e). Concentrations of $\mathrm{Cd}$ in [20-100 lm] plankton fractions were not related to the Gironde Estuary water discharges. Note that this fraction reflects the particle size ingested by oysters and represents at least $90 \%$ of plankton, as $95 \%$ of terrigenic particles are smaller than $201 \mathrm{~m}$. In April and May, Cd in 20-100 $1 \mathrm{~m}$ plankton was of $0.25 \mathrm{mg} \mathrm{kg}^{-1}$ whereas it increased to values 2 -fold higher $\left(0.55 \mathrm{mg} \mathrm{kg}^{-1}\right)$ in June and July (Fig. 3e). These increasing $\mathrm{Cd}$ concentrations in plankton were correlated to decreasing $<0.2$

and $<0.021 \mathrm{~m} \quad \mathrm{Cd}_{\mathrm{g}}$ in waters, suggesting $\mathrm{Cd}$ uptake and bioaccumulation by plankton. In sediments, Cd concentrations were constant over the 3 months, $0.17 \pm 0.08 \mathrm{mg} \mathrm{kg}^{-1}$, except a slight increase in 

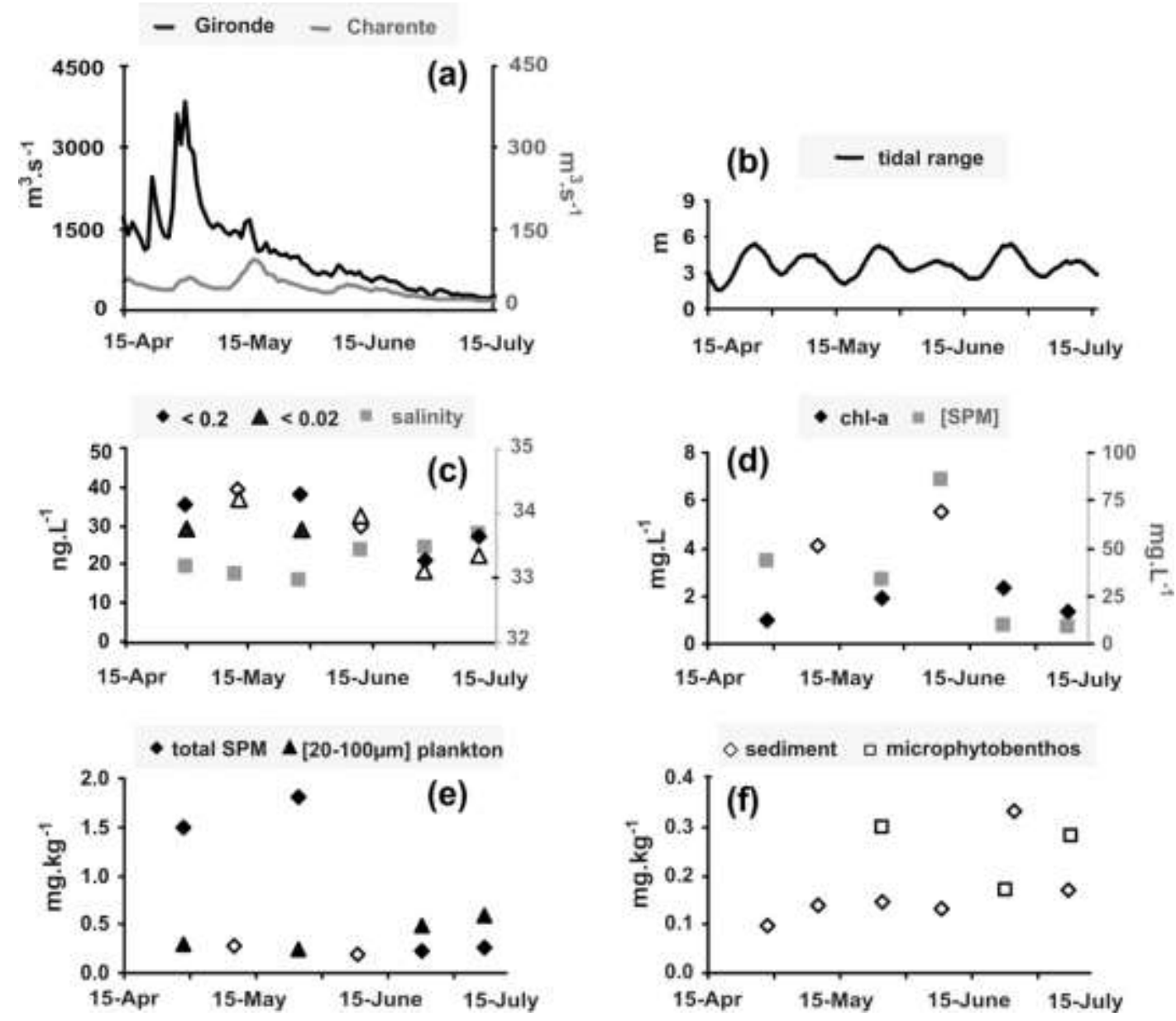

Fig. 3. Temporal parameters variations in surface water at Ronce-Les-Bains mudflat from 15th April to 15th July 2009. (a) daily Gironde Estuary over Charente River freshwater discharges $\left(\mathrm{m}^{3} \mathrm{~s}^{-1}\right)$; (b) tidal range (m); (c) dissolved $\mathrm{Cd}(<0.2$ and $<0.02 \mathrm{~lm})$ concentrations (ng $\left.\mathrm{L}^{-1}\right)$ over salinity sampling during high tide $(\mathrm{HT})$; (d) Chl-a over SPM concentrations $\left(\mathrm{mg} \mathrm{L}^{-1}\right)$ sampling during HT; (e) Cd concentrations in total SPM and [20-100 l m] plankton (mg kg ${ }^{-1}$ ) sampling during HT; (f) Cd concentrations in sediments and microphytobenthos $\left(\mathrm{mg} \mathrm{kg}^{-1}\right)$ sampling at low tide. Solid symbols represent sampling at high tide and open symbols represent sampling at low tide.

June (Fig. 3f). Although microphytobenthos was sampled according to two different methods, we encountered issues with diatoms migration in situ and in the laboratory during the beginning of the survey. Accordingly, we were able to measure Cd concentra- tions in microphytobenthos only three times during the survey and we observed highly variable concentrations close or 2-fold higher than $\mathrm{Cd}$ in sediments (Fig. 3f).

\subsection{Oysters}

\subsubsection{Oysters condition index}

Condition index (C.I.) increased with time in oysters from bottom (B) and table (T) conditions, and were significantly different from one month to another. However, the differences between conditions for each sampling period were not statistically significant (Fig. 5g). After 2 and 3 months sampling, we observed gametogenesis in oysters from both conditions without spawning. Oyster mortality, controlled for each condition and sampling time, was of $22-26 \%$ after 3 months and was not significantly different between the two rearing conditions, contrary to previous studies (Soletchnik et al., 2005; Gagnaire et al., 2006). Furthermore, mortality was in the same range as that of 18th months-old oysters reared in the bay and was related to the 2009 summer mortality events which occurred in all coastal French waters (ROCCH, 2010).

\subsubsection{Cadmium bioaccumulation}

Cadmium concentrations $\left(\operatorname{lg~g}^{-1} \mathrm{dw}\right)$ were measured in oysters gills, digestive glands and rests of tissues from $\mathrm{T}$ and $\mathrm{B}$ conditions at the beginning of the survey (control) and after one, two and three months (Fig. $5 \mathrm{a}-\mathrm{c}$ ). Concentrations in gills from $\mathrm{T}$ and $\mathrm{B}$ were significantly different from control $\left(2.1 \pm 0.4 \mathrm{lg} \mathrm{g}^{-1} \mathrm{dw}\right.$; control) after 3 months survey, respectively $4.5 \pm 0.9$ and $3.3 \pm 0.3 \mathrm{lg} \mathrm{g}^{-1}$ $\mathrm{dw}(p<0.05)$. Concentrations in digestive glands were significantly different from control $\left(2.0 \pm 0.4 \mathrm{lg} \mathrm{g}^{-1} \mathrm{dw}\right.$; control $)$ after 2 months (5.41 \pm 0.9 and $4.77 \pm 0.8 \mathrm{lg} \mathrm{g}^{-1} \mathrm{dw} \mathrm{T}$ and $\left.\mathrm{B}\right)$ and continued to increase after 3 months survey but we did not observe different bioaccumulation levels between the conditions $(8.84 \pm 2.0$ and $6.97 \pm 1.5 \mathrm{lg} \mathrm{g}^{-1} \mathrm{dw} \mathrm{T}$ and $\left.\mathrm{B} ; p>0.05\right)$. In the rest of tissues, concentrations were significantly different from control $(3.6 \pm 0.3$ $\left.\lg \mathrm{g}^{-1} \mathrm{dw}\right)$ after 2 month $(p<0.05)$, reaching values of $5.6 \pm 0.6(\mathrm{~T})$ and $5.5 \pm 0.7$ (B) $1 \mathrm{~g} \mathrm{~g} \mathrm{~g}^{-1} \mathrm{dw}$. However, cadmium concentrations considerably decreased during the third month, to values of $0.9 \pm 0.1$ and $1.0 \pm 0.1 \mathrm{lg} \mathrm{g}^{-1} \mathrm{dw}$, in $\mathrm{T}$ and $\mathrm{B}$ tissues after 3 months.

Cadmium burdens $(\mathrm{lg})$ were measured in gills, digestive glands and rest of tissues of oysters from $\mathrm{T}$ and $\mathrm{B}$ conditions at the beginning and after one, two and three months survey (Fig. 5d-f). Cadmium burdens in gills from $\mathrm{T}$ and $\mathrm{B}$ showed similar evolution and were significantly different from control $(0.12 \pm 0.02 \mathrm{lg})$ after two and three months survey. However, measured burdens were signif- 

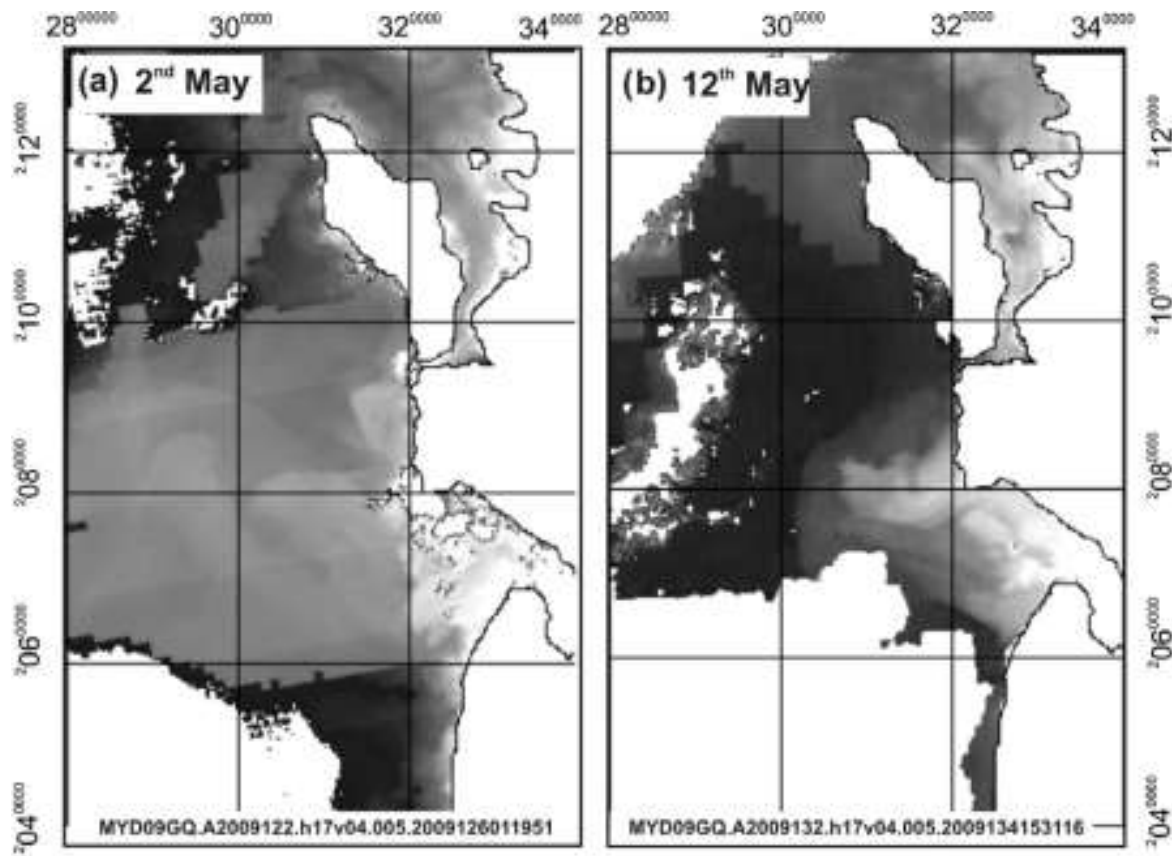

Legend
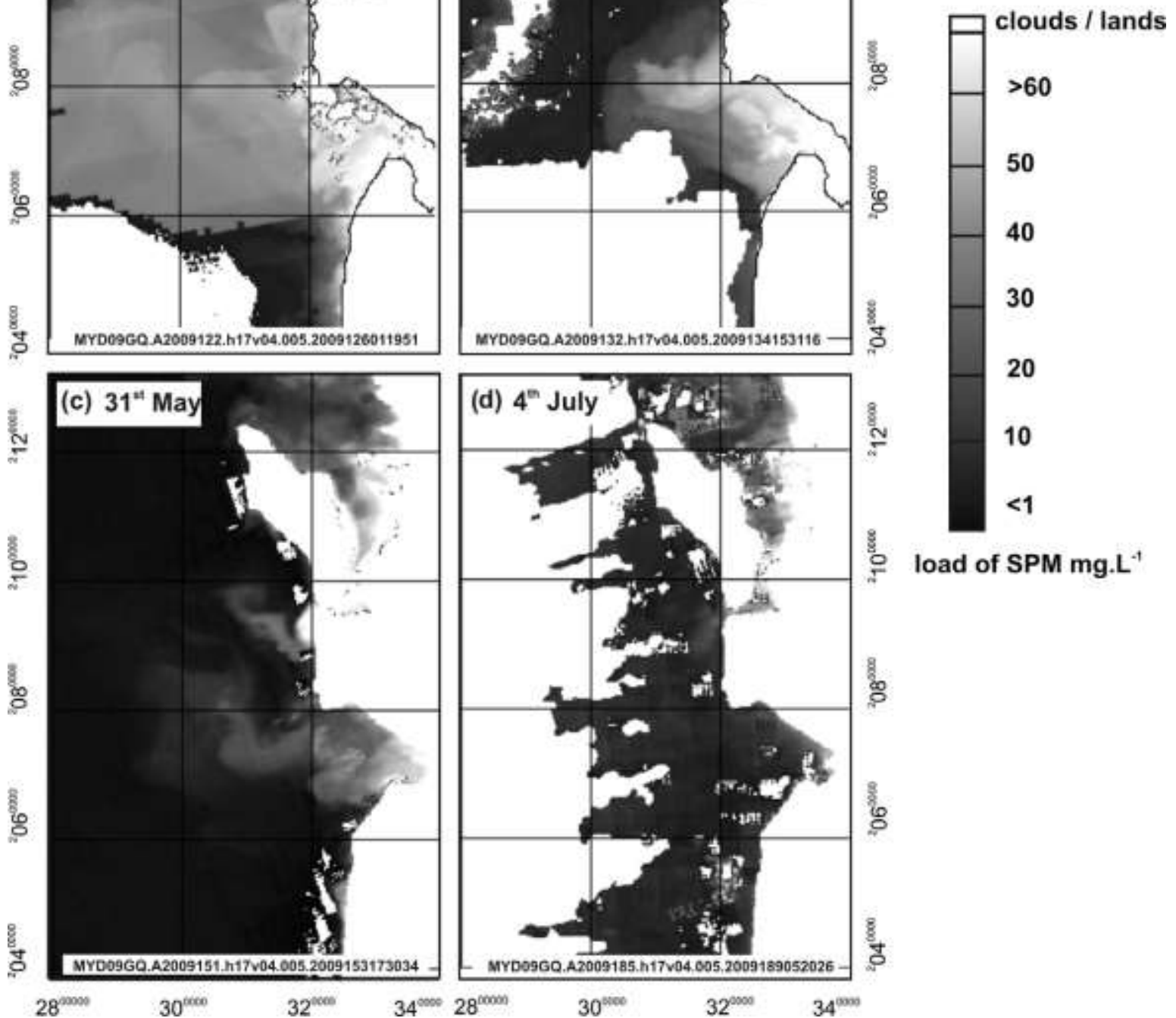

\section{0}

30

20

10

$<1$

load of SPM mg. $\mathrm{L}^{-1}$

蒠

(1)

8

\&

Fig. 4. Modis satellite images of SPM distribution in the mouth of the Gironde Estuary, the coastal area and the Marennes-Oléron Bay during four contrasting Gironde Estuary freshwater discharges conditions. (a) 2nd May (b) 12 th May (c) 31 st may and (d) 4th July.

icantly higher in gills from $\mathrm{T}(0.33 \pm 0.05 \mathrm{lg})$ than from B $(0.21 \pm$ $0.04 \mathrm{lg})$ after 2 months $(p<0.05)$ and also 3 months. In digestive glands, Cd burdens increased with time and were signif- icantly different from control $(0.16 \pm 0.02 \mathrm{lg})$ after 1 month sur- vey. After two and three months, burdens were considerably higher in digestive glands from $\mathrm{T}(0.70 \pm 0.11 \mathrm{lg})$ than from $\mathrm{B}(0.45 \pm 0.06$ $\mathrm{lg})$. Finally, Cd burdens in the rest of tissues increased with time and were significantly different from control $(0.15 \pm$

$0.02 \mathrm{lg}$ ) after 1 month. Higher Cd burden was measured in tissues from $\mathrm{T}(0.82 \pm 0.012 \mathrm{lg})$ than from $\mathrm{B}(0.53 \pm 0.04 \mathrm{lg})$ after 3 months of survey.

\subsubsection{Metallothionein levels}

Metallothionein concentrations ([MT]; nmol $\mathrm{Hg} \mathrm{g}^{-1} \mathrm{ww}$ ) were measured in gills and digestive glands of oysters from $\mathrm{T}$ and $\mathrm{B}$ con- ditions at the beginning and after one, two and three months of survey (Fig. $5 \mathrm{~h}$ and i). In gills, [MT] were relatively constant in oysters from $\mathrm{T}\left(9.7 \pm 1.2 \mathrm{nmol} \mathrm{Hg} \mathrm{g}^{-1} \mathrm{ww}\right.$, control) and decreased in oysters from B conditions $(p<0.05)$ to a minimum of $3.3 \pm 2.5 \mathrm{nmol} \mathrm{Hg} \mathrm{g}{ }^{-1}$ ww after 2 months. In digestive glands, we also measured constant [MT] in T oysters $\left(39.1 \pm 16.9 \mathrm{nmol} \mathrm{Hg} \mathrm{g}^{-1}\right.$ $\mathrm{ww}$, control) and decreasing [MT] after 2 months in oysters from B (25.4 $\left.\pm 7.1 \mathrm{nmol} \mathrm{Hg} \mathrm{g}^{-1} \mathrm{ww}, 3 \mathrm{M}, p<0.05\right)$.

\section{Discussion}

\subsection{Tidal cycle variation}

The dynamics of $\mathrm{Cd}$ and geochemical parameters, observed during four tidal cycles, showed similar tendencies, despite different 

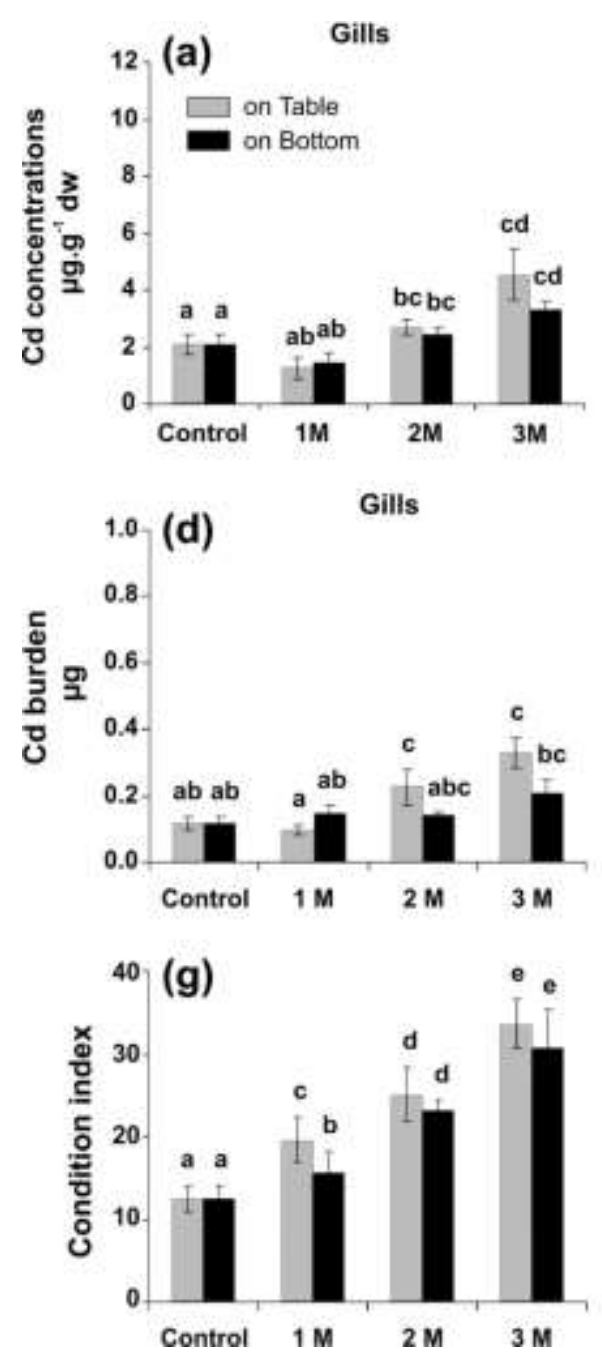
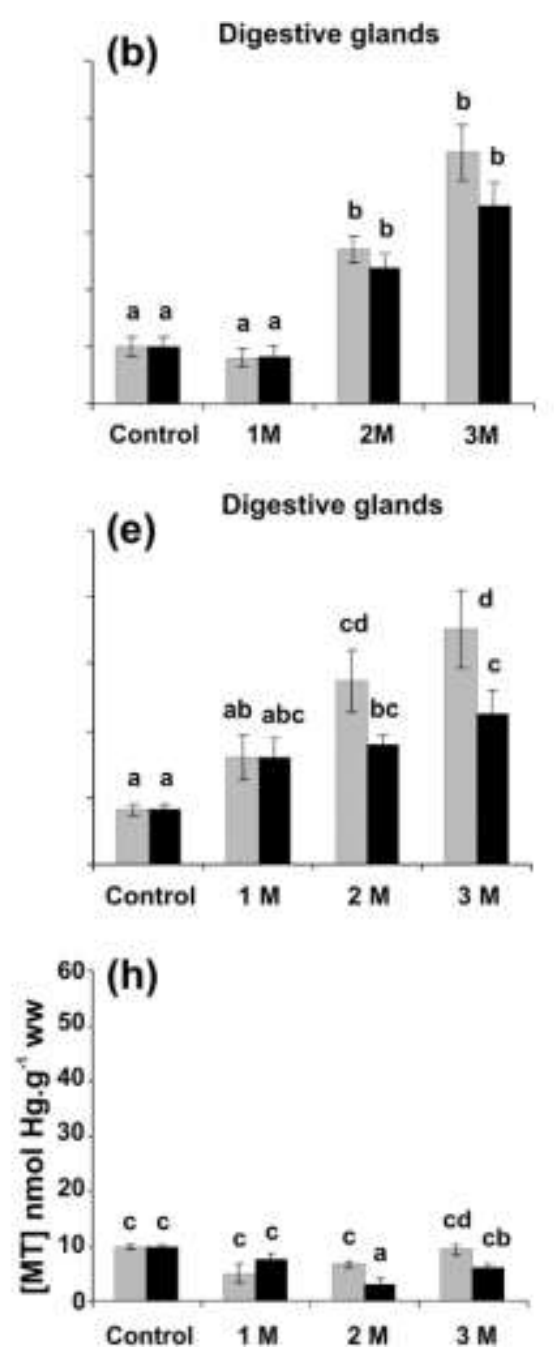
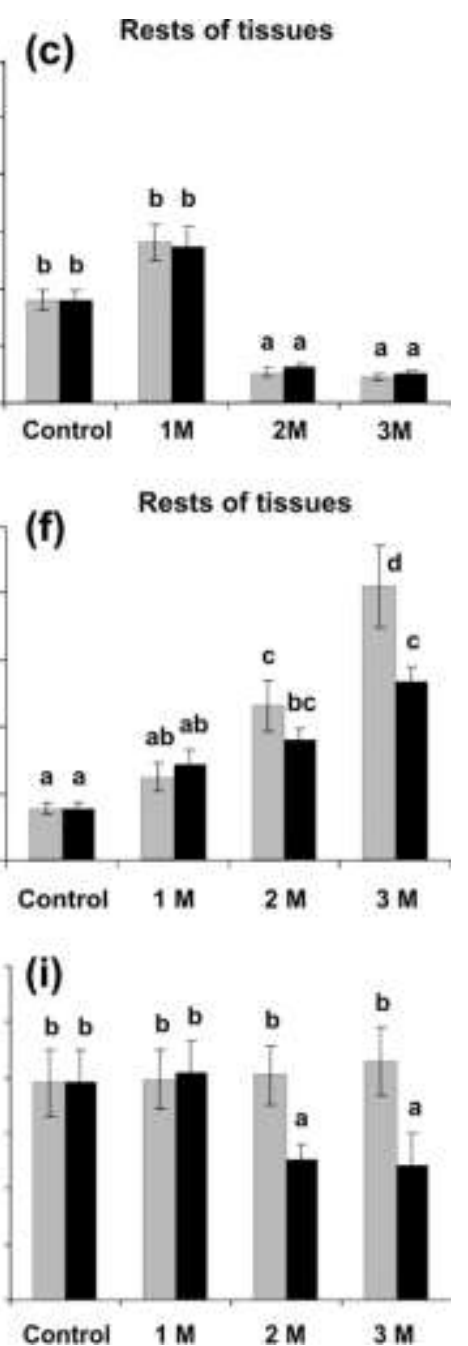

Fig. 5. (a-c) Cadmium concentrations ( $\operatorname{lg~g}^{-1} \mathrm{dw}$ ) in gills (a), digestive glands (b) and rests of tissues (c) of oysters reared on Table (grey) and on Bottom (black) at the beginning and after one, two and three months of cultivation. d-f) Cadmium burdens ( $\mathrm{g}$ ) in gills (d), digestive glands (e) and rests of tissues (f) of oysters reared on Table (grey) and on Bottom (black) at the beginning and after one, two and three months of cultivation. Letters correspond to statistical non-parametric Kruskall-Wallis test analysis, considering a probability of $p<0.05$ as significant; g) Condition index of oysters reared on Table (grey) and on Bottom (black) at the beginning and after one, two and three months of cultivation; (h) and (i) Metallothionein concentrations (nmol Hg g ${ }^{-1} \mathrm{ww}$ ) in gills (h) and digestive glands (i) of oysters reared on Table (grey) and on Bottom (black) at the beginning and after one, two and three months of cultivation. Letters correspond statistical variance method (ANOVA) and LSD test analyses, considering a probability of $p<0.05$ as significant.

concentration ranges. From high tide to mid ebb, $\mathrm{Cd}$ partitioning between the dissolved and particulate phases was constant as presumed by the weak exchange between the water column and sediment. During the beginning of flood, tidal sediment resuspension was weaker than expected and was observed for 10-15 cm water depth. Particulate $\mathrm{Cd}$ concentrations associated to tidal sediment resuspension were constant, showing (i) the absence of particulate influx from sediment and from microphytobenthos or (ii) the achieved equilibrium state between Cd concentrations in SPM, microphytobenthos and sediments. Dissolved Cd concentrations were also constant over increasing tidal range and bottom resuspension, suggesting that dissolved Cd release from sediment due to diagenetic processes was not measurable in contrast to previous work by Gonzalez (1992) in sediments from the tidal MOB. The absence of Cd release may also imply that Cd desorption from microphytobenthos (Pigeot et al., 2006) may be negligible in the water column. Thus, Cd partitioning between dissolved and particulate phases did not seemed to be controlled by sediment resuspension, i.e. not influenced by tidal cycle, suggesting the importance of hydrodynamic for Cd Cycle.

\subsection{Cadmium partitioning}

Cadmium concentrations in sediments from the south of the bay showed typical low values (Strady et al., accepted CSR; Gonzalez et al., 1991). Compared to most environments cited in the literature (e.g. Accornero et al., 2008), these concentrations are low and can be related to unpolluted lagoon, as Vaccares and Leucate Lagoon, located in the northwestern Mediterranean sea (RNO, 1998; Accornero et al., 2008). Geochemical background concentrations in sediments were differentiated from anthropogenic inputs by assessing the degree of metal enrichment using the enrichment factor EF (Zhang and Liu, 2002; Essien et al., 2009). Previously, Cd concentrations in sediments were normalized with thorium (Th) concentrations (Masson et al., 2006; Coynel et al., 2007; Larrose et al., 2010) to compensate natural variability due to grain-size variations (e.g. mineral composition) and to detect any anthropogenic metal contributions (Loring, 1991). Then, EF was defined as the ratio of Th normalized Cd concentrations in sediments over Th normalized Cd levels in the bottom sediment of a core from the West Gironde Mud Patch, considered as representative of the 
regional geochemical natural background (Larrose et al., 2010). Sediments presented $\mathrm{EF}<1.5$, suggesting natural weathering processes, except in June, where $1.5<\mathrm{EF}<3$ indicated a minor $\mathrm{Cd}$ enrichment. Accordingly, although the sediments in the study area were mainly derived from the Gironde Estuary (Parra et al., 1999) they were Cd-depleted (by desorption) and released low $\mathrm{Cd}$ amount by diagenetic processes during flood resuspension (Gonzalez, 1992). The punctual minor enrichment observed was not due to Cd-rich microphytobenthos (Pigeot et al., 2006), as during this study $\mathrm{Cd}$ levels in microphytobenthos were globally similar to those in sediments (Fig. 3e). We rather suggest deposition of SPM, which are globally more concentrated in $\mathrm{Cd}$ than sediments (Fig. 3; Gonzalez et al., 1991).

Temporal Cd variations in SPM were within the typical concentration ranges observed in the southern bay (Gonzalez et al., 1991; Dabrin, 2009). However, high Cd levels in SPM were not related to Chl-a concentrations and were significantly higher than those in 20-100 $1 \mathrm{~m}$ plankton. Thorium normalized Cd concentrations in SPM rather suggested anthropogenic inputs in April and May $(\mathrm{Cd} / \mathrm{Th}>0.1)$ and natural geochemical background levels in June and July $(\mathrm{Cd} / \mathrm{Th} \sim 0.02)$, supporting that temporal $\mathrm{Cd}$ variations could be related to Gironde water discharges, as higher Cd concentrations were observed at HT sampling, when the Gironde Estuary influence is at maximum. Experimental studies of $\mathrm{Cd}$ desorption processes in the salinity gradient related to the turbid Gironde Estuary have shown that Cd desorption was enhanced by increasing salinity (Chiffoleau et al., 2001) and mainly limited by high SPM concentrations and decreasing water residence time (Masson, 2007). Considering that during flood events, a major part of SPM entering the Gironde Estuary are expulsed to the coastal area through the plume, we suggest that during the first month of the survey, fresh riverine particles (Cd $4.0 \pm 3.0 \mathrm{mg} \mathrm{kg}^{-1}$, Garonne, La Réole, pers. comm.) may have reached the coastal area within the Gironde plume (Fig. 4). We hypothesize that those particles were not entirely desorbed in the Gironde Estuary turbid waters, and so continued to desorb in the low turbid and saline waters of the MOB. This hypothesis is consistent with Cd-rich SPM sam- pled at $\mathrm{HT}$ in the bay at the beginning of the survey (Table 1), In contrast, during low water discharges from mid-June to July, the plume was less extended in the coastal zone and the turbidity zone had moved into the estuary (Fig. 4), inducing Cd desorption inside the estuary (Robert et al., 2004; Audry et al., 2007; Dabrin et al., 2009). In this condition, particles potentially reaching the bay are quasi Cd-depleted. Thus, SPM sampled at RLB site presented a Gironde signature during the 1-2 months, showing the potential influence of (i) Gironde water discharges, (ii) plume extension and position and (iii) desorption processes occurring in the Gir- onde Estuary on Cd concentrations in SPM of the MOB. The Cha- rente Estuary discharges were constant during this survey, and did not induce noticeable variations in SPM.

In the MOB, previous studies have shown that dissolved Cd concentrations varied locally and temporally. In fact, lower concentrations were observed in the northern part (Gonzalez et al., 1991) and larger variability was observed in the south during a year survey $\left(43 \pm 15 \mathrm{ng} \mathrm{L}^{-1}\right.$; (Dabrin, 2009). Although the Charente and Seudre Rivers $\mathrm{Cd}$ inputs contribute to the $\mathrm{Cd}$ budget of the bay, they did not directly explain the increased concentrations observed in the southern bay (Dabrin, 2009). During this survey, $\mathrm{Cd}_{\mathrm{d}}$ concentrations varied and were related to Gironde Estuary water discharges (Fig. 3). Thus, temporal Cd variability could be re- lated to (i) dissolved inputs from the Gironde waters, (ii) SPM desorption processes in the bay and/or (iii) plankton uptake. A previous study on $\mathrm{Cd}_{\mathrm{d}}$ export from the Gironde Estuary showed that $\mathrm{Cd}_{\mathrm{d}}$ levels were highly variable in the high salinity Gironde waters, $\mathrm{S}=32-34.7, \mathrm{Cd}: 15-90 \mathrm{ng} \mathrm{L}^{-1}$ (Dabrin et al., 2009). We hypothesize that increasing $\mathrm{Cd}_{\mathrm{d}}$ concentrations in the MOB originated from Gir- onde Cd-rich waters masses connected to the Maumusson Inlet during the first month of the survey. In the previous section, we discussed the desorption processes still occurring in the coastal area and in the bay during April and May. We can now suggest that desorption of observed Cd-rich particles enhanced $\mathrm{Cd}_{\mathrm{d}}$ concentrations (Comans and Van Dijk, 1988; Turner, 1996) in the bay. As we did not sample Gironde waters during the survey, the dominant process (inputs or desorption) occurring in the bay cannot be determined. However, we pointed out the key role played by the connection of the Gironde plume to the Maumusson Inlet on increasing $\mathrm{Cd}$ in the southern bay. In June and July, $\mathrm{Cd}_{\mathrm{d}}$ concentrations decreased in the bay simultaneously to increasing $\mathrm{Cd}$ in 20$1001 \mathrm{~m}$ plankton (Fig. 3), suggesting phytoplankton uptake. This process, well observed during algae blooms (Luoma et al., 1998; Luengen et al., 2007), was already suggested for the bay by Gonzalez et al. (1991) to complete Cd budget but was not yet observed.

\subsection{Cd bioaccumulation in oysters}

Oysters cultivated in the water column (T) and on the sediment surface (B) grew and developed similarly, as confirmed by the condition index (Fig. 5g). Kinetics of $\mathrm{Cd}$ bioaccumulation showed clearly increasing $\mathrm{Cd}$ concentrations $\left(\mathrm{lg} \mathrm{g}^{-1}, \mathrm{dw}\right)$ in gills and digestive glands, whereas it significantly decreased in the rest of tissues after 2 months, because of increasing weight due to gonad development (Fig. $5 \mathrm{a}-\mathrm{c}$ ). To avoid $\mathrm{Cd}$ concentrations dilution by weight effect, we used kinetics of Cd burdens (lg). Cd burdens clearly increased over time and showed higher burdens in digestive glands and rest of tissues that in gills (Fig. 5d-f). After 3 months, enrichment factors $\left([\mathrm{Cd}]_{3 \mathrm{M}} /[\mathrm{Cd}]_{\text {control }}\right)$ of $\mathrm{Cd}$ in tissues of oysters exposed from $\mathrm{T}$ and $\mathrm{B}$ were respectively 3.0 and 2.2 in gills, 4.7 and 3.2 in digestive glands and 4.9 and 3.4 in the rest of tissues. Thus, $\mathrm{Cd}$ accumulation was clearly higher in oysters growing in the water column than near the bottom, as it has been observed for oyster larvae in eastern North America (Ng et al., 2010). We also determined the bioaccumulation factor (BAF), defined as the ratio of $\mathrm{Cd}$ concentration in the organism to the concentration in water (Gobas and Morrison, 2000; DeForest et al., 2007). To avoid the weight effect issue encountered, we calculated a new adapted $\mathrm{BAF}\left(\mathrm{BAF}_{\text {adap }}\right)$ from the $\mathrm{Cd}$ burden $(\mathrm{lg})$, and not from the Cd concentration $\left(\operatorname{lg~g}^{-1}\right)$, and for the three tissues (gills, digestive glands and rests), by assuming a mean $\mathrm{Cd}_{\mathrm{d}}$ levels of $40 \mathrm{ng} \mathrm{L}^{-1}$ during the first 2 months and of $30 \mathrm{ng} \mathrm{L}^{-1}$ for the whole 3 months. This $\mathrm{BAF}_{\mathrm{adap}}$ showed different factors for different organs, with higher and similar $\mathrm{BAF}_{\text {adap }}$ in digestive glands and rests of tissues than in gills, after 1, 2 and 3 months (Fig. 6), suggesting gill contamination via the direct pathway and subsequent internal redistribution of $\mathrm{Cd}$ to other organs and tissues (Strady et al., in press; Lekhi et al., 2008) in oysters from both conditions. Higher Cd bioaccumulation in digestive glands than in gills was also observed in previous studies but was not related to Cd environmental levels (Geret and Cosson, 2000; Geffard et al., 2002). The $\mathrm{BAF}_{\text {adap }}$ between conditions showed general higher factors in all tissues from $T$ than from $B$ (Fig. 6), showing that direct pathway of contamination cannot explain the difference of $\mathrm{Cd}$ bioaccumulation observed between the two rearing conditions. Submersion time of oysters reared in the water column (T) was globally lower than oysters reared on bottom (B) and was depending on tidal range. From an altimetry survey (ALTUS device), conducted in the same time, and especially the pressure sensor, we roughly determined a general submersion time of $90 \%$ for B and of $80 \%$ for T. As the filtration rate of oysters is about 4 L.h ${ }^{-1}$ (Bougrier et al., 1995) and as it is not influenced by SPM load (Gerdes, 1983), we can estimate that the potential difference of accumulated $\mathrm{Cd}$ by direct pathway (filtration) between the two submersion time is of $1 \%$ and could induce a small difference between $\mathrm{BAF}_{\text {adap }}$ in $\mathrm{T}$ and $\mathrm{B}$. Thus, we hypothesize that additive 


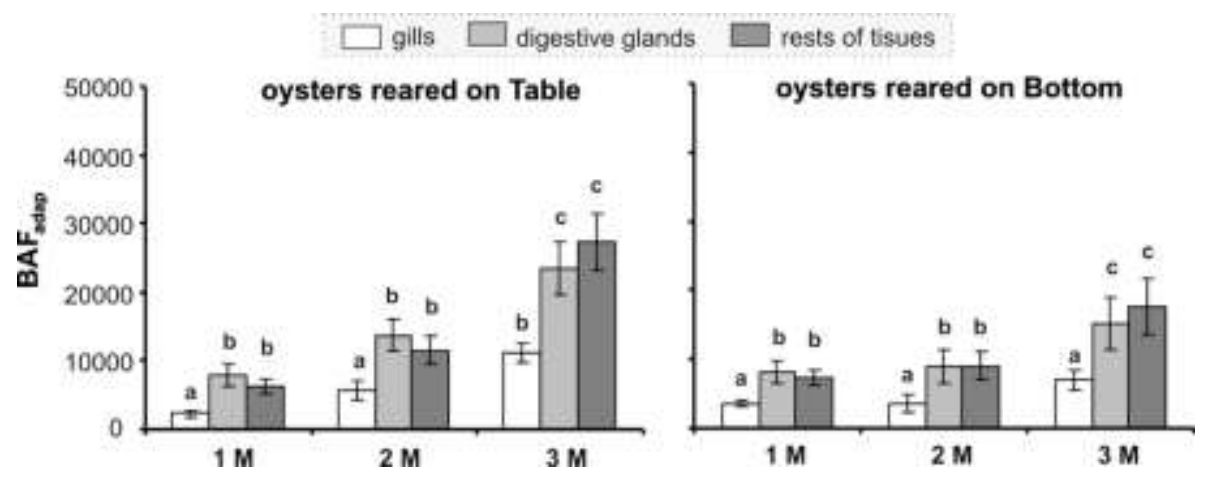

Fig. 6. Comparison of Bioaccumulation factor (adapted) for oysters reared on Table and on Bottom in gills, digestive glands and rests of tissues.

preponderant diet exposure in one condition over the other could

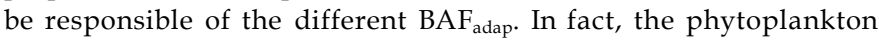
biomass in spring is generally composed by $90 \%$ of pelagic and $10 \%$ of benthic microalgae (Malet et al., 2008). Consequently, oysters in the water column would rather filter pelagic phytoplankton, whereas for oysters on the sediment surface one would expect higher contributions of benthic microalgae. As concentrations measured in phytoplankton were 2 to 3 -fold higher than in microphytobenthos, we suggest that oysters reared on tables fed by a majority of phytoplankton, which was higher Cd-contaminated. In contrast, we suggest that oysters reared on bottom mainly fed on a higher proportion of benthic microalgae, which had lower $\mathrm{Cd}$ levels. However, we would like to specify that $\mathrm{Cd}$ concentra- tions measured in microphytobenthos during this study were 4- 5-fold lower than those measured by Pigeot et al. (2006). These concentrations differences could be due to (i) either the sampling method used which could induce remaining sediments with epipelic diatoms and (ii) from the previous authors sampling site, northern in the bay, performed about 10 years ago in a different season. Thus, we do not exclude Cd bioaccumulation in oysters via microphytobenthos feeding. In conclusion, during the 3 months survey, oysters were contaminated via both direct and trophic pathways.

Metallothionein (MT) levels were higher in digestive glands than in gills (Fig. 5h and i), as previously reported in different contaminated environments and for different oyster ages (Mouneyrac et al., 1998; Geret and Cosson, 2000; Geffard et al., 2001, 2002). After 3 months, MT were constant in gills and digestive glands from oysters reared on $\mathrm{T}$ (Fig. $5 \mathrm{~h}$ and i), attesting the absence of MT induction for detoxifying processes. However, MT decreased after 2 months in organs from oysters reared on B (Fig. 5h and i) where $\mathrm{Cd}$ burdens were significantly lower compared to tables (Fig. 5e). Those variations are quite surprising as they were not related to gametogenesis, although previous studies on diploid and triploid oysters showed that gametogenesis induced increasing MT in diploid oysters (Marie, 2005). Nevertheless, oysters were in their first phase of reproduction. Previous studies on the effect of the sediment nearness on the metabolic activity of Crassostrea gigas have shown that despite similar survival and growth at the water column and bottom rearing levels, the ATP activity was significantly reduced in oysters reared on the sediment (Le Moullac et al., 2007). Furthermore, measurements of metabolic enzyme activities have suggested that oysters feed less and experience an oxygen deficiency when reared on the sediments (Le Moullac et al., 2007). Depleted oxygen in waters (or at the water-sediment interface) induced reduced metabolism and protein synthesis in crabs Carcinus maeras (Mente et al., 2003) and in eels Anguilla anguilla (Pierron et al., 2007). Thus, decreased metabolism and ATP activities in oysters reared closed to the sediment is consistent with decreasing protein synthesis, and thus MT synthesis and concentrations observed in oysters reared on B (Fig. 5h and i).
The difference of metabolic activity between oyster rearing conditions (Le Moullac et al., 2007) could also suggest decreasing filtration rate and decreasing bioaccumulated $\mathrm{Cd}$ by direct and trophic pathways in oysters reared on $B$.

Finally, these results are highly relevant to commercial oyster production. In fact, a regular observation of Gironde Estuary inputs, dissolved and particulate (SPM and plankton) Cd concentrations in the MOB would lead to a better management of oysters cultivation. Furthermore, cultivation on the sediment surface could be an alternative limiting bioaccumulation, although mortality could be enhanced (Gagnaire et al., 2006). However, Cd concentrations in the whole oyster tissues nearly reached the consumption level of $5 \mathrm{lg} \mathrm{g}^{-1} \mathrm{dw}$ (e.g. $\left.1 \mathrm{lg} \mathrm{g}^{-1} \mathrm{ww}, \mathrm{EU}\right)$ after 1 month $(4.3 \pm 0.4$ $\operatorname{lg~g}^{-1} \mathrm{dw}$ in oysters cultivated on $\mathrm{T}$ and $3.8 \pm 0.3 \mathrm{lg} \mathrm{g}^{-1} \mathrm{dw}$ in oysters cultivated on B) but are expected to decrease due to rapid growth (Rasmussen et al., 2007), highlighting the need for similar experimentations with adult oysters.

\section{Conclusions}

The present study pointed out the relevance of an adapted and pluridisciplinary sampling strategy to understand $\mathrm{Cd}$ bioaccumulation by oysters in a specific environment. Environmental geochemical parameters, metal bioaccumulation and hydrodynamic variations were surveyed and considered simultaneously. This environmental overview allowed us to better understand the factors influencing and controlling $\mathrm{Cd}$ distributions and bioaccumulation. In fact, cadmium partitioning was not influenced by tidal sediment resuspension on mudflat but was mainly controlled by the regional hydrodynamic and the Gironde plume inputs. Those pluridisciplinary surveys were relevant to demonstrate that in the Marennes-Oléron Bay, oysters bioaccumulated $\mathrm{Cd}$ via direct and trophic contamination pathways.

\section{Acknowledgements}

The authors thank H. Derriennic, G. Oggian, C. Bossy, L. Dutruch and E. Maneux for their support during sampling, laboratory analysis and L. Lanceleur for his advices for statistical analysis. This study was supported by CYTRIX EC2CO VOTR'TRAM project and a grant from the French Ministry of Research.

\section{References}

Accornero, A., Gnerre, R., Manfra, L., 2008. Sediment concentrations of trace metals in the Berre lagoon (France): an assessment of contamination. Arch. Environ. Contam. Toxicol. 54, 372-385.

Audry, S., Blanc, G., Schäfer, J., 2003. Cadmium in the Lot-Garonne River system: fluxes, predictive model and mass balance. J. Phys. IV: JP, 71-74.

Audry, S., Blanc, G., Schäfer, J., Guerin, F., Masson, M., Robert, S., 2007. Budgets of $\mathrm{Mn}, \mathrm{Cd}$ and $\mathrm{Cu}$ in the macrotidal Gironde Estuary (SW France). Mar. Chem. 107, 433-448. 
Barrera-Escorcia, G., Vanegas-Pérez, C., Wong-Chang, I., 2010. Filtration rate, assimilation and assimilation efficiency in Crassostrea virginica (Gmelin) fed with tetraselmis suecica under cadmium exposure. J. Environ. Sci. Health - Part A Toxic/Hazard. Subst. Environ. Eng. 45, 14-22.

Baudrimont, M., Schäfer, J., Marie, V., Maury-Brachet, R., Bossy, C., Boudou, A., Blanc, G., 2005. Geochemical survey and metal bioaccumulation of three bivalve species (Crassostrea gigas, Cerastoderma edule and Ruditapes philippinarum) in the Nord Médoc salt marshes (Gironde estuary, France). Sci. Total Environ. 337, 265-280.

Bendell, L.I., Feng, C., 2009. Spatial and temporal variations in cadmium concentrations and burdens in the Pacific oyster (Crassostrea gigas) sampled from the Pacific north-west. Mar. Pollut. Bull. 58, 1137-1143.

Bertin, X., Chaumillon, E., Sottolichio, A., Pedreros, R., 2005. Tidal inlet response to sediment infilling of the associated bay and possible implications of human activities: the Marennes-Oléron Bay and the Maumusson Inlet, France. Cont. Shelf Res. 25, 1115-1131.

Blanc, G., Lapaquellerie, Y., Maillet, N., Anschutz, P., 1999. Acadmium budget for the Lot-Garonne fluvial system (France). Hydrobiologia 410, 331-341.

Boisson, F., Goudard, F., Durand, J.P., Barbot, C., Pieri, J., Amiard, J.C., Fowler, S.W., 2003. Comparative radiotracer study of cadmium uptake, storage, detoxification and depuration in the oyster Crassostrea gigas: potential adaptive mechanisms. Mar. Ecol. Prog. Ser. 254, 177-186.

Bougrier, S., Geairon, P., Deslous-Paoli, J.M., Bacher, C., Jonquieres, G., 1995. Allometric relationships and effects of temperature on clearance and oxygen consumption rates of Crassostrea gigas (Thunberg). Aquaculture 134, 143-154. Chiffoleau, J.F., Auger, D., Chartier, E., Michel, P., Truquet, I., Ficht, A., Gonzalez, J.L., Romaña, L.A., 2001. Spatiotemporal changes in cadmium contamination in the Seine estuary (France). Estuaries 24, 1029-1040.

Comans, R.N.J., Van Dijk, C.P.J., 1988. Role of complexation processes in cadmium mobilization during estuarine mixing. Nature 336, 151-154

Coynel, A., Schäfer, J., Blanc, G., Bossy, C., 2007. Scenario of particulate trace metal and metalloid transport during a major flood event inferred from transient geochemical signals. Appl. Geochem. 22, 821-836.

Dabrin, A., 2009. Mécanismes de transfert des éléments traces métalliques et réactivité estuarienne. Cas des systèmes Gironde, Charente, Seudre et Baie de Marennes Oléron. PhD, University of Bordeaux, p. 375.

Dabrin, A., Schäfer, J., Blanc, G., Strady, E., Masson, M., Bossy, C., Castelle, S., Girardot, N., Coynel, A., 2009. Improving estuarine net flux estimates for dissolved cadmium export at the annual timescale: application to the Gironde Estuary. Estuar, Coast Shelf. Sci. 84, 429-439

DeForest, D.K., Brix, K.V., Adams, W.J., 2007. Assessing metal bioaccumulation in aquatic environments: the inverse relationship between bioaccumulation factors, trophic transfer factors and exposure concentration. Aquat. Toxicol. 84, 236-246.

Doxaran, D., Froidefond, J.M., Castaing, P., Babin, M., 2009. Dynamics of the turbidity maximum zone in a macrotidal estuary (the Gironde, France): observations from field and MODIS satellite data. Estuar, Coast Shelf Sci. 81, 321-332.

Essien, J.P., Antai, S.P., Olajire, A.A., 2009. Distribution, seasonal variations and ecotoxicological significance of heavy metals in sediments of cross river estuary mangrove swamp. Water, Air, Soil Pollut. 197, 91-105

Gagnaire, B., Soletchnik, P., Madec, P., Geairon, P., Le Moine, O., Renault, T., 2006. Diploid and triploid Pacific oysters, Crassostrea gigas (Thunberg), reared at two heights above sediment in Marennes-Oleron Basin, France. Difference in mortality, sexual maturation and hemocyte parameters. Aquaculture 254, 606-616.

Geffard, A., Amiard-Triquet, C., Amiard, J.C., Mouneyrac, C., 2001. Temporal variations of metallothionein and metal concentrations in the digestive gland of oysters (Crassostrea gigas) from a clean and a metal-rich site. Biomarkers 6, 91-107.

Geffard, A., Amiard, J.C., Amiard-Triquet, C., 2002. Kinetics of metal elimination in oysters from a contaminated estuary. Comp. Biochem. Physiol. - C Toxicol. Pharmacol. 131, 281-293

Gerdes, D., 1983. The Pacific oyster Crassostrea gigas. Part I. Feeding behaviour of larvae and adults. Aquaculture 31, 195-219.

Geret, F., Cosson, R.P., 2000. The use of metallothioneins as biomarker of metal contamination: variability between sites and organs in the oyster Crassostrea gigas. Oceanol. Acta 23, 261-271.

Gobas, F.A.P.C., Morrison, H.A.,2000. Bioconcentration and biomagnification in the aquatic environment. In: Boethling, R.S., Mackay, D. (Eds.), Handbook of Property Estimation Methods for Chemicals. Lewis Publishers, Boca Raton, FL pp. $189-231$

Gonzalez, J.L., 1992. Comportement du cadmium et du mercure lors de la diagenèse précoce et flux à l'interface eau-sédiments en zone littorale. Thèse, Université Bordeaux 1, France, p. 247.

Gonzalez, J.L., Boutier, B., Chiffoleau, J.F., Auger, D., Noel, J., Truquet, I., 1991. Distribution of $\mathrm{Cd}$ and $\mathrm{Hg}$ in the Bay of Marennes-Oleron. Oceanol. Acta 14, 559-568.

Guarini, J.M., Blanchard, G.F., Bacher, C., Gros, P., Riera, P., Richard, P., Gouleau, D., Galois, R., Prou, J., Sauriau, P.G., 1998. Dynamics of spatial patterns of microphytobenthic biomass: inferences from a geostatistical analysis of two comprehensive surveys in Marennes-Oleron Bay (France). Mar. Ecol. Prog. Ser. $166,131-141$.

Hédouin, L., Metian, M., Teyssié, J.L., Fichez, R., Warnau, M., 2010. Delineation of heavy metal contamination pathways (seawater, food and sediment) in tropical oysters from New Caledonia using radiotracer techniques. Mar. Pollut. Bull.
Jouanneau, J.M., Boutier, B., Chiffoleau, J.F., Latouche, C., Philipps, I., 1990 . Cadmium in the Gironde fluvioestuarine system: behaviour and flow. Sci. Total Environ. $97-98,465-479$

Kruzynski,G.M., 2004. Cadmium in oysters and scallops: the BC experience. Toxicol. Lett. 148, 159-169.

Lafon, V., Petus, C., Dabrin, A., Froidefond, J.M., Doxaran, D., Maneux, E., Castaing, P., 2009. Gironde and Adour plume dynamics using MODIS imagery - dynamique des panaches de la Gironde et de l'Adour par imagerie MODIS. 31èmes Journée de l'Hydraulique de la SHF «Morphodynamique et gestion des sédiments dans les estuaires, les baies et les deltas», Paris, France.

Larrose, A., Coynel, A., Schäfer, J., Blanc, G., Massé, L., Maneux, A., 2010. Assessing the current state of the Gironde Estuary by mapping priority contaminant distribution and risk potential in surface sediment. Appl. Geochem. 25, 19121923.

Latouche, C., 1988. Cadmium pollution in the Gironde estuary. Bull. Inst. Géol. Bassin d'Aquitaine 44, 15-21.

Le Moullac, G., Fleury, P.G., Le Coz, J.R., Moal, J., Samain, J.F., 2007. Effect of sediment nearness on the metabolic enzyme activity and energy state of the oyster Crassostrea gigas. Aquat. Liv. Resour. 20, 279-286.

Lekhi, P., Cassis, D., Pearce, C.M., Ebell, N., Maldonado, M.T., Orians, K.J., 2008. Role of dissolved and particulate cadmium in the accumulation of cadmium in cultured oysters (Crassostrea gigas). Sci Total. Environ. 393, 309-325.

Loring, D.H., 1991. Normalization of heavy-metal data from estuarine and coastal sediments. ICES J. Mar. Sci. 48,101-115

Luengen, A.C., Raimondi, P.T., Flegal, A.R., 2007. Contrasting biogeochemistry of six trace metals during the rise and decay of a spring phytoplankton bloom in San Francisco Bay. Limnol. Oceanogr. 52, 1112-1130.

Luoma, S.N., Van Geen, A., Lee, B.G., Cloern, J.E., 1998. Metal uptake by phytoplankton during a bloom in South San Francisco Bay: implications for metal cycling in estuaries. Limnol. Oceanogr. 43, 1007-1016.

Malet, N., Sauriau, P.G., Ryckaert, M., Malestroit, P., Guillou, G., 2008. Dynamics and sources of suspended particulate organic matter in the Marennes-Oléron oyster farming bay: insights from stable isotopes and microalgae ecology. Estuar, Coast Shelf Sci. 78, 576-586.

Marie, V., 2005. Etude de la réponse des métallothionéines chez les bivalves, Corbicula fluminea, Dreissena polymorpha et Crassostrea gigas, après exposition au cadmium et au zinc. Approches in situ et expérimentales PhD, Université Bordeaux1, p. 461.

Marie, V., Gonzalez, P., Baudrimont, M., Bourdineaud, J.P., Boudou, A., 2006. Metallothionein response to cadmium and zinc exposures compared in two freshwater bivalves, Dreissena polymorpha and Corbicula fluminea. BioMetals 19, 399-407

Masson, M., 2007. Sources et transferts métalliques dans le bassin versant de la Gironde. Réactivité et mécanismes géochimiques dans l'estuaire fluvial de la Gironde. PhD, Université Bordeaux1, p. 366.

Masson, M., Blanc, G., Schäfer, J., 2006. Geochemical signals and source contributions to heavy metal $(\mathrm{Cd}, \mathrm{Zn}, \mathrm{Pb}, \mathrm{Cu})$ fluxes into the Gironde Estuary via its major tributaries. Sci. Total Environ. 370, 133-146.

Mente, E., Legeay, A., Houlihan, D.F., Massabuau, J.C., 2003. Influence of oxygen partial pressures on protein synthesis in feeding crabs. Am. J. Physiol. - Regul. Integr. Comp. Physiol., 284.

Mouneyrac, C., Amiard, J.C., Amiard-Triquet, C., 1998. Effects of natural factors (salinity and body weight) on cadmium, copper, zinc and metallothionein-like protein levels in resident populations of oysters Crassostrea gigas from a polluted estuary. Mar. Ecol. Prog. Ser. 162, 125-135.

Ng, T.Y.T., Chuang, C.Y., Stupakoff, I., Christy, A.E., Cheney, D.P., Wang, W.X., 2010. Cadmium accumulation and loss in the Pacific oyster Crassostrea gigas along the west coast of the USA. Mar. Ecol. Prog. Ser. 401, 147-160.

Parra, M., Castaing, P., Jouanneau, J.M., Grousset, F., Latouche, C., 1999. Nd-Sr isotopic composition of present-day sediments from the Gironde Estuary, its draining basins and the WestGironde mud patch (SW France). Cont. Shelf Res. $19,135-150$

Pierron, F., Baudrimont, M., Gonzalez, P., Bourdineaud, J.P., Elie, P., Massabuau, J.C., 2007. Common pattern of gene expression in response to hypoxia or cadmium in the gills of the European glass eel (Anguilla anguilla). Environ. Sci. Technol. 41, 3005-3011.

Pigeot, J., Miramand, P., Guyot, T., Sauriau, P.G., Fichet, D., Le Moine, O., Huet, V., 2006. Cadmium pathways in an exploited intertidal ecosystem with chronic cadmium inputs (Marennes-Oléron, Atlantic coast, France). Mar. Ecol. Prog. Ser. $307,101-114$

Raillard, O., Menesguen, A., 1994. An ecosystem box model for estimating the carrying capacity of a macrotidal shellfish system. Mar. Ecol. Prog. Ser. 115 $117-130$.

Rasmussen, R.S., Mommissey, M.T., Cheney, D., 2007. Effect of age and tissue weight on the cadmium concentration in Pacific oysters (Crassostrea gigas). J. Shellfish Res. 26, 173-179.

RAZLEC-IFREMER, 2009. <http://www.ifremer.fr/lerpc/reseaux/hydro/resul_hydro. htm>.

Reinfelder, J.R., Wang, W.X., Luoma, S.N., Fisher, N.S., 1997. Assimilation efficiencies and turnover rates of trace elements in marine bivalves: a comparison of oysters, clams and mussels. Mar. Biol. 129, 443-452.

RNO, 1998. Surveillance du milieu marin. Travaux du RNO. Ifremer et Ministère de $l^{\prime}$ Aménagement du territoire et de l'Environnement.

RNO, 2006. Surveillance du milieu marin. Travaux du RNO. Ifremer et Ministère de l'Ecologie et du Développement Durable. 
Robert, S., Blanc, G., Schäfer, J., Lavaux, G., Abril, G., 2004. Metal mobilization in the Gironde Estuary (France): the role of the soft mud layer in the maximum turbidity zone. Mar. Chem. 87, 1-13.

ROCCH, 2010. Bulletin de la Surveillance de la Qualité du Milieu Marin Littoral Résultats acquis jusqu'en 2009. Edition 2010. Ifremer/RST.LER/PC/10.01/ Laboratoire Environnement Ressources des Pertuis Charentais, p. 95.

Schäfer, J., Blanc, G., Lapaquellerie, Y., Maillet, N., Maneux, E., Etcheber, H., 2002 Ten-year observation of the Gironde tributary fluvial system: fluxes of suspended matter, particulate organic carbon and cadmium. Mar. Chem. 79, $229-242$

Soletchnik, P., Faury, N., Razet, D., Goulletquer, P., 1998. Hydrobiology of the Marennes-Oléron bay. Seasonal indices, analysis of trends from 1978 to 1995. Hydrobiologia 386, 131-146.

Soletchnik, P., Lambert, C., Costil, K., 2005. Summer mortality of Crassostrea gigas (Thunberg) in relation to environmental rearing conditions. J. Shellfish Res. 24 197-207.
Strady, E., Blanc, G., Schäfer, J., Coynel, A., Dabrin, A., 2009. Dissolved uranium, vanadium and molybdenum behaviours during contrasting freshwater discharges in the Gironde Estuary (SW France). Estuar, Coast Shelf Sci. 83, 550560 .

Strady, E., Schäfer, J., Baudrimont, M., Blanc, G., in press. Tracing cadmium contamination kinetics and pathways in oysters (Crassostrea gigas) by stable Cd isotope spike experiments. Ecotoxicol. Environ. Saf.

Turner, A., 1996. Trace-metal partitioning in estuaries: importance of salinity and particle concentration. Mar. Chem. 54, 27-39.

Yentsch, C.S., Menzel, D.W., 1963. A method for the determination of phytoplankton chlorophyll and phaeophytin by fluorescence. Deep Sea Res. Oceanogr. Abst. 10 221-231.

Zhang, J., Liu, C.L., 2002. Riverine composition and estuarine geochemistry of particulate metals in China - weathering features, anthropogenic impact and chemical fluxes. Estuar, Coast Shelf Sci 54, 1051-1070. 